\title{
Beare-Stevenson Cutis Gyrata Syndrome
}

National Cancer Institute

\section{Source}

National Cancer Institute. Beare-Stevenson Cutis Gyrata Syndrome. NCI Thesaurus.

Code C123813.

A rare, autosomal dominant inherited disorder caused by mutations in the FGFR2 gene. It is characterized by the premature fusion of the bones of the skull (craniosynostosis) and a skin abnormality called cutis gyrata. The craniosynostosis results in a cloverleaf-shaped skull, wide-set eyes, ear abnormalities, underdeveloped upper jaw, and developmental delays. Cutis gyrata is characterized by a wrinkled skin appearance, especially on the face, near the ears, and on the palms and soles. 